\title{
Ebstein's anomaly of the tricuspid and mitral valves in an otherwise normal heart
}

\author{
M DUSMET, * I OBERHAENSLI, $\dagger$ J N COX * \\ From the Departments of Pathology ${ }^{\star}$ and Paediatrics, $\dagger$ Faculty of Medicine, University of Geneva, Geneva, \\ Switzerland
}

SUMMARY A case in which there was Ebstein's anomaly of both the tricuspid and mitral valve is described: the structure of the heart was otherwise normal.

The anomaly of the tricuspid valve first described by Ebstein in $1866^{12}$ accounts for approximately $1 \%$ of all heart malformations. ${ }^{34}$ It consists of the downward displacement of the basal insertion of the septal and posterior valve leaflets, which are almost always dysplastic. ${ }^{56}$ In $42-97 \%$ of cases there is also an atrial septal defect or a patent foramen ovale and the anomaly may be associated with various other cardiac malformations. ${ }^{78}$ Mital prolapse, contractionrelaxation abnormalities of the left ventricle, and mitral stenosis have also been reported, ${ }^{39-11}$ In nearly half the affected hearts there is malformation of the left-sided atrioventricular valve in corrected transposition of the great arteries. ${ }^{12}$ In the very rare cases in which there is malformation of the true mitral valve ${ }^{61314}$ the posterior leaflet is displaced downwards and there may be shortening of the outflow chamber.

We report a case of Ebstein's anomaly of both atrioventricular valves in an otherwise normal heart. This, to the best of our knowledge, has not been reported before.

\section{Case report}

The patient, a boy, was born at term on 6 May 1985 to a 31 year old woman (para 2, gravida 2) after an uneventful pregnancy (no history of drug administration or of infectious diseases). The Apgar scores at 1,5 , and 10 minutes were 6,7 , and 8 but the baby was cyanosed. Hypertelorism, retrognathia, widely spaced nipples, and stiffness of elbows and knees (with maximum extension to $130^{\circ}$ ) were noted.

Requests for reprints to Dr J N Cox, Department of Pathology, Centre Médical Universitaire, 1 rue Michel Servet, $\mathrm{CH}-1211$ Geneva 4, Switzerland.
There was left cryptorchidism and slight epispadias. Tachypnoea (92/minute) was seen at birth; pulses were regular (130/minute) and symmetrical in all four extremities. A systolic/diastolic murmur was heard soon after birth but by two weeks of age it became a 4-5/6 pansystolic regurgitant murmur and a 3/6 diastolic tricuspid murmur; B1 was soft and B2 normally split. Chest $x$ ray demonstrated cardiomegaly with a cardiothoracic index of 0.63 . Electrocardiography showed right atrial and right ventricular hypertrophy, right bundle branch block, and right axis deviation $\left(+180^{\circ}\right)$ which became extreme $\left(220^{\circ}\right)$ over the following months.

Echocardiographic studies were performed at the age of two days, six days, and six months. These showed situs solitus as well as atrioventriculoarterial concordance and connection. Both atria were significantly dilated and both atrioventricular valve insertions were abnormal: the anterior tricuspid leaflet was normally attached but the posterior and septal leaflets were displaced towards the apex. All three leaflets were dysplastic with thickened free edges. The anterior leaflet showed undulating, whiplike motions towards the right ventricular wall. Important tricuspid insufficiency was noted on Doppler $N$ echocardiographic examination. The mitral valve had a normally attached but thickened anterior leaflet; the insertion of the posterior leaflet was displaced towards the apex and the leaflet was dysplastic (fig 1a and b). All chordae were shortened. Doppler echocardiography also showed considerable mitral $\stackrel{\oplus}{\oplus}$ insufficiency. In addition, there was evidence of a ductus arteriosus at the first examination, which closed by six days.

Physiological pulmonary hypertension and resistance regressed during the first six days of life and the signs of right ventricular failure and cyanosis 


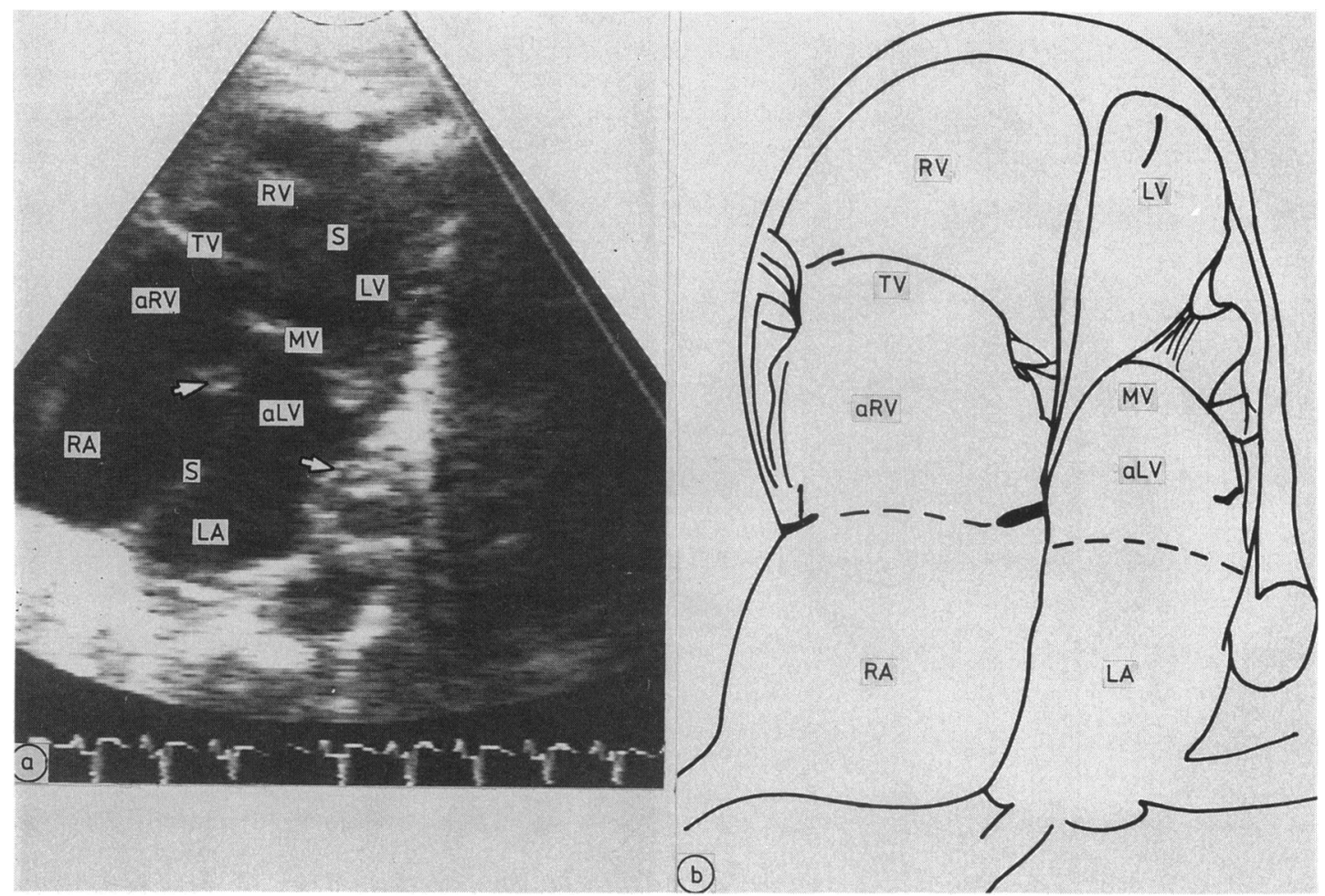

Fig 1 Real time echocardiogram (a) and diagram (b) of the four chamber view of a case of Ebstein's anomaly of both atrioventricular valves. This shows apical displacement of the insertion of the septal and posterior leaflets of the tricuspid valve (TV) and of the insertion of the septal portion of the posterior leaflet of the mitral valve (MV). The atrialised portions of the right $(a R V)$ and left $(a L V)$ ventricles are well defined by the corresponding annulus fibrosis at the antrioventricular groove (arrowed). The moderator band is seen in the functional right ventricle ( $R V$ ). The interventricular and interatrial septa $(S)$ are intact. $R A$, right atrium, $L A$, left atrium, $L V$, left ventricle.

became less conspicuous. Nevertheless, digoxin treatment was required.

Bilateral hydronephrosis caused by urethral strictures required drainage by cystostomy. After this renal function became normal. At the age of one month the patient was readmitted with a urinary infection. In October 1985 the proximal urethral mucosa was sutured to the skin to relieve urethral obstruction.

On 7 February 1986 the child was admitted with vomiting and diarrhoea, fever $\left(39^{\circ}-40^{\circ} \mathrm{C}\right)$, dehydration, and tachycardia $(180 / \mathrm{min})$ caused by viral gastroenteritis. There was no evidence of bacterial infection and the cerebrospinal fluid examination was unremarkable. Intravenous rehydration was necessary. At $4 \mathrm{pm}$ on 8 February he had a sudden cardiorespiratory arrest and despite immediate and vigorous attempts at resuscitation he died one hour later.
PATHOLOGICAL EXAMINATION:

At necropsy the child was a well nourished boy weighing $7 \mathrm{~kg}$ (P 30) for a crown-heel length of $66 \mathrm{~cm}$ (P 30). Cranial circumference was $45 \cdot 8 \mathrm{~cm}$ (P 50). There was straw-coloured fluid in the abdomen $(25 \mathrm{ml})$ and in both pleural cavities $(8$ and $10 \mathrm{ml})$.

Heart.-The heart weighed $95 \mathrm{~g}$ (normal $42 \mathrm{~g}$ ). The right atrium was dilated and hypertrophied (mean muscle thickness $2-3 \mathrm{~mm}$ ). The structure of the interatrial septum was normal with a $3 \mathrm{~mm}$ diameter foramen ovale. The tricuspid valve was cone shaped, and its leaflets were thickened with rolled edges. It was difficult to identify individual leaflets (fig 2). The site of insertion of its anterior portion was normal while the insertions of the septal and posterior portions were displaced downwards. The chordae were short and thickened to such an extent that in some areas they were absent. The atrialised supravalvar right ventricle did not show noticeable thinning or 

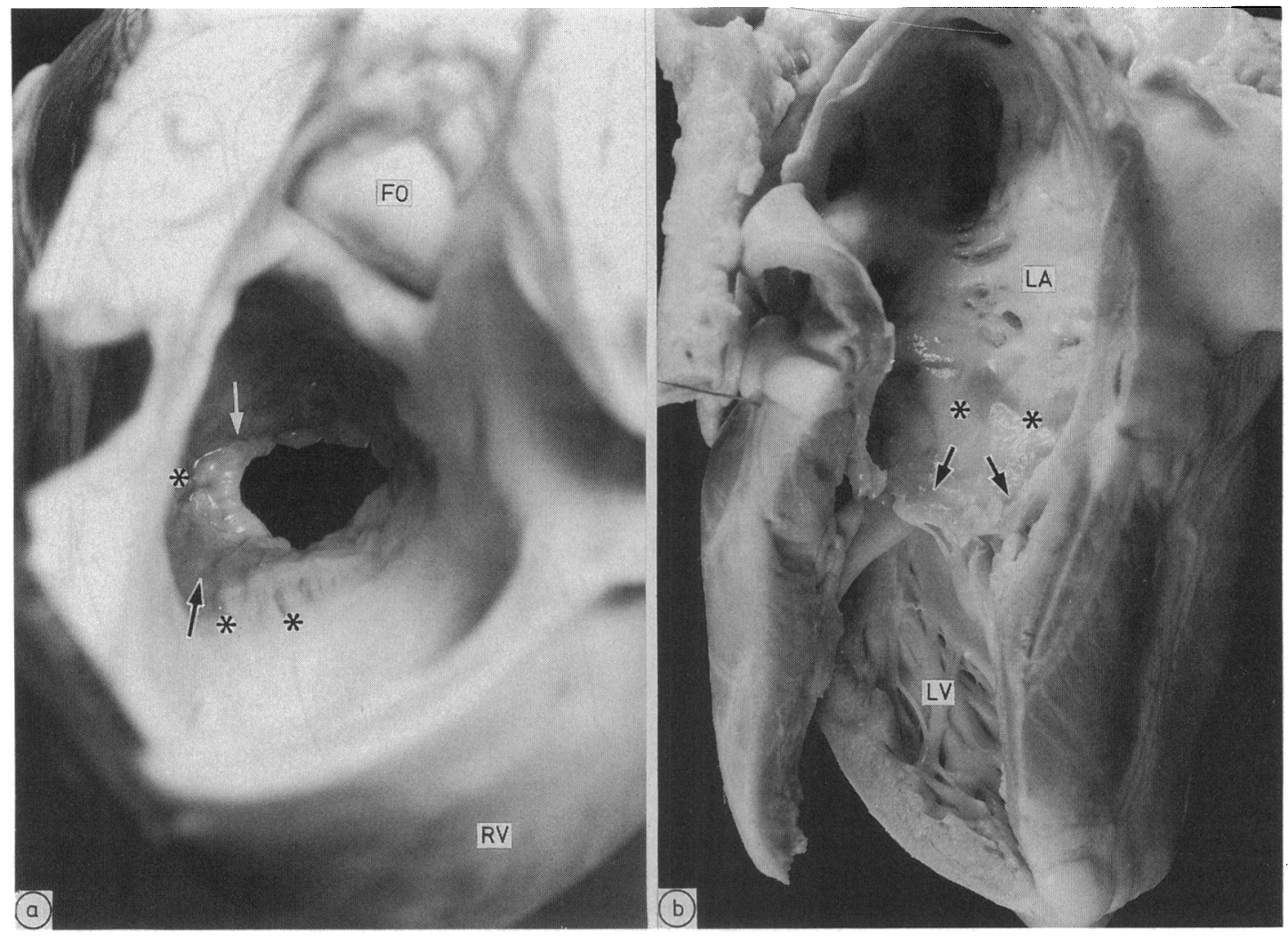

Fig 2 (a) Tricuspid valve seen from right atrium in a case of Ebstein's anomaly. The basal insertion of posterior and septal portions is indicated (arrowed). Note narrow anterior leaflet. *annulus fibrosus; $R V$, right ventricle; FO, foramen ovale. (b) Left heart showing the downward displacement of the basal insertion of the septal part of the mitral valve which is dysplastic and inserted directly on to the medial papillary muscle (arrowed). There is dilatation and hypertrophy of left atrium. * position of normal insertion of mitral valve; $L A$, left atrium; $L V$, left ventricle.

dilatation. The rest of the right ventricle was both dilated and markedly hypertrophied, but the configuration of the outflow tract and pulmonary valve was normal. The left atrium was dilated and hypertrophied (fig $2 \mathrm{~b}$ ). The mural portion of the posterior mitral valve leaflet was displaced downwards to the upper limit of the trabecular portion of the left ventricle (fig 2b). Both leaflets were dysplastic, and the chordae were significantly shortened and thickened or absent (fig 2b). The atrialised supravalvar ventricular wall was also thickened. The hypertrophic left ventricle and the aortic valve were otherwise normal. Histological examination showed several small foci of acute right myocardial necrosis that were attributed to cardiac massage.

The lungs showed signs of congestion and moderate interstitial and intra-alveolar oedema without evidence of infection. There was moderate right hydronephrosis caused by hypertrophic stenosis of the pyeloureteral junction and evidence of chronic pyelonephritis.

\section{Discussion}

In typical cases of Ebstein's anomaly the normally inserted anterior leaflet of the tricuspid valve may be $N$ a large and sail-like structure ${ }^{415}$ whereas the septal ${ }^{\circ}$ and posterior valves are usually dysplastic and there $O$ is downward displacement of their basal in- $\omega$ sertion. ${ }^{615}$ This arrangement permits the anterior valve to function as a monocusp valve after ventricu- $\infty$ lar plication. ${ }^{15}$ Furthermore, the right ventricle is $\mathbb{D}$ divided into an atrialised supravalvar portion with? quite thin walls and a trabecular, functional $\frac{0}{0}$ portion. ${ }^{3515}$ The size and degree of the dysfunction $\frac{\vec{D}}{\mathbb{D}}$ of the upper part of the ventricle as well as the degree $\stackrel{\square}{\stackrel{1}{9}}$ of valvar insufficiency determine right ventricular $\stackrel{\mathbb{Q}}{\square}$ function and right atrial pressure; when right atrial 
pressure exceeds left atrial pressure a right-left shunt through an interatrial communication or a patent foramen ovale causes cyanosis. In the present case the anterior leaflet of the tricuspid valve was not enlarged, and the dysplasia affected all leaflets roughly to the same degree, so that the insufficient tricuspid orifice was centrally sited. Regression of cyanosis during the first few days of life was mainly the result of closure of the ductus arteriosus. Because pressures in both atria were probably raised to a similar degree it is unlikely that there was important shunting through the patent foramen ovale.

The morphology of the mitral valve was similar to two previously reported cases of Ebstein's anomaly of the true mitral valve. ${ }^{613}$ In the case described by Allenstein et al, however, there was a large ventricular septal defect and a hypoplastic left ventricle which contributed to the malformation of the mitral valve. ${ }^{14}$ There was clinical and morphological evidence of mitral valve insufficiency in the case described by Ruschhaupt et al. ${ }^{13}$ Recently, Leung et al have described two additional cases of this very rare anomaly. ${ }^{16}$ In our case insufficiency of the dysplastic mitral valve was identified by Doppler echocardiography and hypertrophy and dilatation of the left atrium.

Ebstein's anomaly of the tricuspid valve can be confidently diagnosed by real time echocardiography. ${ }^{17-19}$ The normally inserted mitral valve is used as the reference marker to indicate the correct position of the right valve insertion in the apical four chamber view. This is the most appropriate view to assess the annulus and the apical displacement of the insertion of the leaflets of the right atrioventricular valve and their motion. Additional views permit grading of displacement of the atrioventricular valve as well as a detailed evaluation of the severity and the specific form of any associated malformations.

In our case the diagnosis proved to be difficult because both atrioventricular valves were affected to a similar degree by the apical displacement of leaflet insertion and there was no mitral reference point for examination of the tricuspid valve. Furthermore, because both valves were severely dysplastic and did not close during systole there was bilateral atrioventricular valve insufficiency. The correlation between the echocardiographic and the pathological findings was good and retrospective analysis of the echocardiographic recordings in the light of the pathological findings confirmed the initial diagnosis.

Right bundle branch block was seen in our case. This is a frequent electrocardiographic abnormality in Ebstein's anomaly, as are modifications reflecting the atrial hypertrophy and the Wolff-Parkinson-White pattern of conduction. 82021 These electrocardiographic findings are often the re- sult of right bundle branch malpositions and of accessory atrioventricular connections ${ }^{358}$ which predispose these patients to sudden, fatal arrhythmias. ${ }^{22-25}$ We believe that such an arrhythmia is the most plausible cause of death in this case. The presence of an accessory atrioventricular connection and progressive, severe heart failure are the two major indications for surgical treatment of Ebstein's anomaly. ${ }^{815}$ Neither was seen in the present case; furthermore replacement of both atrioventricular valves would have required anticoagulation and further valve replacement with growth and this treatment would not have prevented sudden, possibly fatal, arrhythmias. ${ }^{15}$

Despite an extensive review of published reports, we did not find another report of the association of Ebstein's anomaly of the tricuspid valve with the same malformation of the mitral valve.

\section{References}

1 Ebstein W. Ueber einen sehr seltenen Fall von Insufficienz der Valvular tricuspidalis, bedingt durch eine angeborene hochgradige Missbildung derselben. Archiv für Anatomie, Physiologie und wissenschaftliche Medizin 1866;238-54.

2 Schiebler GL, Gravenstein JS, Van Mierop LHS. Ebstein's anomaly of the tricuspid valve. Translation of original description with comments. Am J Cardiol 1968;22:867-73.

3 Lev M, Liberthson RR, Joseph RH, et al. The pathologic anatomy of Ebstein's disease. Arch Pathol 1970;90:334-43.

4 Anderson KR, Lie JT. Pathologic anatomy of Ebstein's anomaly of the heart revisited. $A m J$ Cardiol 1978;41:739-45.

5 Anderson KR, Zuberbuhler JR, Anderson RH, Becker AE, Lie JT. Morphologic spectrum of Ebstein's anomaly of the heart. A review. Mayo Clin Proc 1979;54:174-80.

6 Becker AE, Anderson RH. Atrioventricular valve malformations. In: Becker AE, Anderson RH, eds. Pathology of congenital heart disease. London: Butterworths, 1981:137-63.

7 Watson H. Natural history of Ebstein's anomaly of tricuspid valve in childhood and adolescence. An international co-operative study of 505 cases. $\mathrm{Br}$ Heart $J$ 1974;36:417-27.

8 Westaby S, Karp RB, Kirklin JW, Waldo AL, Blackstone EH. Surgical treatment in Ebstein's malformation. Ann Thorac Surg 1982;34:388-95.

9 Worms AM, Ravault MC, Ethevenot G, Hoeffel JC, Pernot C. Prolapsus mitral et anomalies ventriculaires gauches dans la malformation d'Ebstein de la tricuspide. A propos de 17 observations. Arch Mal Coeur 1980;73:499-508.

10 Roberts WC, Glancy DL, Seningen RP, Maron BJ, Epstein SE. Prolapse of the mitral valve (floppy 
valve) associated with Ebstein's anomaly of the tricuspid valve. Am J Cardiol 1976;38:377-82.

11 Monibi AA, Neches WH, Lenox CC, Park SC, Mathews RA, Zuberbuhler JR. Left ventricular anomalies associated with Ebstein's malformation of the tricuspid valve. Circulation 1978;57:303-6.

12 Anderson KR, Danielson GK, McGoon DC, Lie JT. Ebstein's anomaly of the left-sided tricuspid valve. Pathological anatomy of the valvular malformation. Cardiovasc Surg 1978;58:I-87-91.

13 Ruschhaupt DG, Bharati S, Lev $M$. Mitral valve malformation of Ebstein type in absence of corrected transposition. Am J Cardiol 1976;38:109-12.

14 Allenstein BJ, Amromin GD, Henning AJ. An unusual cardiac anomaly: Ebstein-like malformation of the left atrioventricular valve, masquerading as a dextrocardia. Report of a case. Dis Chest 1963;44:642-8.

15 Danielson GK, Fuster V. Surgical repair of Ebstein's anomaly. Ann Surg 1982;196:499-504.

16 Leung M, Rigby ML, Anderson RH, Wyse RKH, Macartney FJ. Reversed offsetting of the septal attachments of the atrioventricular valves and Ebstein's malformation of the morphologically mitral valve. $\mathrm{Br}$ Heart $J$ 1987;57:184-7.

17 Gussenhoven WJ, Spitaels SEC, Bom N, Becker AE. Echocardiographic criteria for Ebstein's anomaly of tricuspid valve. Br Heart J 1980;43:31-7.

18 Nihoyannopoulos P, McKenna WJ, Smith G, Foale R.
Echocardiographic assessment of the right ventricle in Ebstein's anomaly: relation to clinical outcome. $J$ Am Coll Cardiol 1986;8:627-35.

19 Shiina A, Seward JB, Edwards WD, Hagler DJ, Tajik AJ. Two-dimensional echocardiographic spectrum of Ebstein's anomaly: detailed anatomic assessment.J Am Coll Cardiol 1984;3:356-70.

20 Giuliani ER, Fuster V, Brandenburg RO, Mair DD. Ebstein's anomaly. The clinical features and natural history of Ebstein's anomaly of the tricuspid valve. Mayo Clin Proc 1979;54:163-73.

21 Kastor JA, Goldreyer BN, Josephson ME, et al. Electrophysiologic characteristics of Ebstein's anomaly of the tricuspid valve. Circulation 1975;52:987-95.

22 Radford DJ, Graff RF, Neilson GH. Diagnosis and natural history of Ebstein's anomaly. Br Heart $J$ 1985;54:517-22.

23 Kumar AE, Fyler DC, Miettinen OS, Nadas AS. Ebstein's anomaly. Clinical profile and natural history. Am J Cardiol 1971;28:84-95.

24 Oh JK, Holmes DR, Hayes DL, Porter CJ, Danielson GK. Cardiac arrhythmias in patients with surgical repair of Ebstein's anomaly. J Am Coll Cardiol 1985;6:1351-7.

25 Rossi L, Thiene G. Mild Ebstein's anomaly associated with supraventricular tachycardia and sudden death: clinicomorphologic features in 3 patients. $\mathrm{Am} \mathrm{J} \mathrm{Car-}$ diol 1984;53:332-4. 